Disusun oleh:

Nur Habibah, M.Si., M.Psi., Psikolog.

Dra. Dwi Nastiti, M.Si.
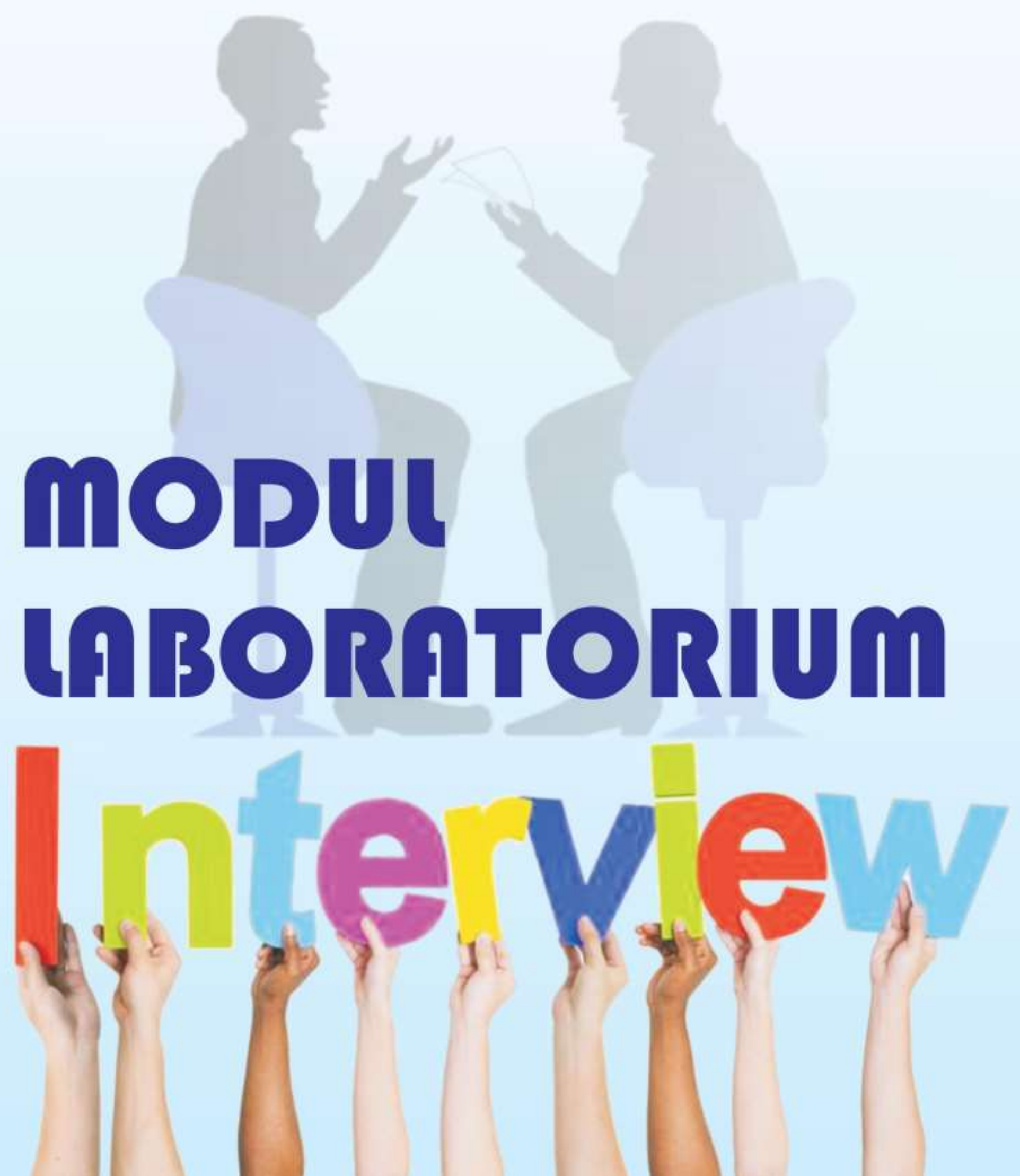


\section{MODUL LABORATORIUM INDIVIDUAL}

\section{INTERVIEW}

Penulis:

Nur Habibah, M.Si., M.Psi., Psikolog

Dra. Dwi Nastiti, M.Si

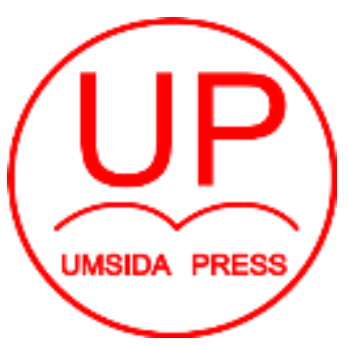

Diterbitkan oleh

\section{UMSIDA PRESS}

Jl. Mojopahit 666 B Sidoarjo

ISBN 978-623-6292-28-0

Copyright $\bigcirc 2021$

Authors

All rights reserved 


\section{MODUL LABORATORIUM INDIVIDUAL INTERVIEW}

\section{Penulis :}

Nur Habibah, M.Si., M.Psi., Psikolog

Dra. Dwi Nastiti, M.Si

\section{ISBN}

978-623-6292-28-0

\section{Editor :}

Ghozali Rusyid Affandy

Nibras Ali Gunanjar

\section{Copy Editor :}

Mayya Kholidah

Design Sampul dan Tata Letak :

Moch. Alfian

Penerbit :

UMSIDA Press

\section{Redaksi :}

Universitas Muhammadiyah Sidoarjo

Jl. Mojopahit No 666B

Sidoarjo, Jawa TImur

Cetakan pertama, Maret 2021

(C) Hak cipta dilindungi undang-undang

Dilarang memperbanyak karya tulis ini dengan suatu apapun tanpa ijin tertulis dari penerbit. 


\section{KATA PENGANTAR}

Alhamdulillahirobbil 'aalamiin, hanya dan hanya karena rahmat Allah SWT, kami dapat menyelesaikan revisi modul Laboratorium Wawancara ini. Modul ini disusun dan diterbitkan sebagai panduan pelaksanaan praktikum di Laboratorium Wawancara bagi mahasiswa Fakultas Psikologi Universitas Muhammadiyah Sidoarjo (UMSIDA).

Kami menyadari bahwa modul ini masih jauh dari sempurna, sehingga terdapat banyak kekurangan. Dengan segala kerendahan hati kami mohon saran dan kritik dari pembaca, guna upaya penyempurnaan revisi modul ini berikutnya.

Pada kesempatan ini kami mengucapkan terima kasih atas kesempatan yang diberikan, kepada yang terhormat:

1. Direktorat Pendidikan Tinggi, melalui Program Hibah Pengembangan (PHP) - PTS 2013, selaku pemberi hibah pengembangan modul laboratorium.

2. Eko Hardiansyah, M.Psi,Psi., selaku Dekan Fakultas Psikologi UMSIDA.

3. Effy Wardati Maryam, S.Psi.,M.Si. selaku Ketua Program Studi Fakultas Psikologi UMSIDA.

4. Ghozali Rusyid Affandi, S.Psi.,M.A. selaku Kepala Laboratorium Fakultas Psikologi UMSIDA.

5. Semua pihak yang telah memberikan bimbingan, motivasi, bantuan dan masukan sehingga dapat terselesaikannya modul ini.

Akhirnya dengan segala kerendahan hati, kami berharap semoga modul ini dapat bermanfaat bagi praktikan, peneliti maupun pembaca, dan semoga upaya yang telah dilakukan ini dapat bernilai ibadah di sisi Allah SWT. Aamiin.

Sidoarjo, 16 Agustus 2020

Tim Penyusun 


\section{DAFTAR ISI}

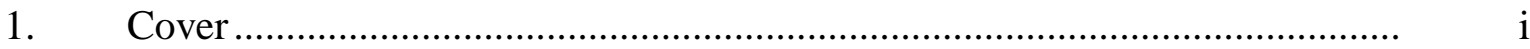

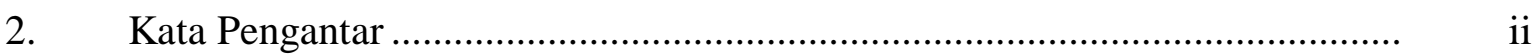

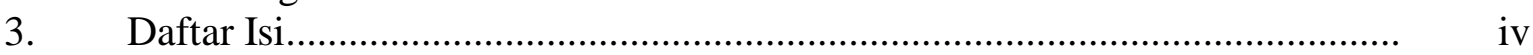

4. Daftar Tabel ............................................................................................. vi

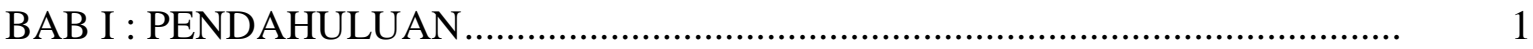

A. Profil Laboratorium .................................................................... 1

B. Manajemen Laboratorium ............................................................... 1

C. Penggunaan Laboratorium................................................................... 2

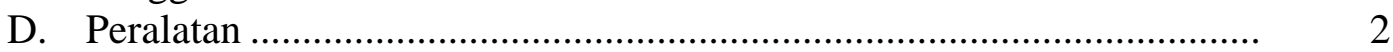

E. Peralatan pendukung................................................................... 3

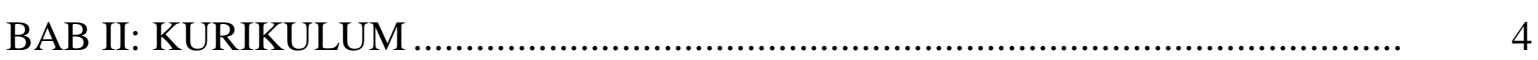

A. Analisis Materi/Instruksional ......................................................... 4

B. Silabus Praktik .......................................................................... 4

C. SAP (Satuan Acara Praktik) .......................................................... 5

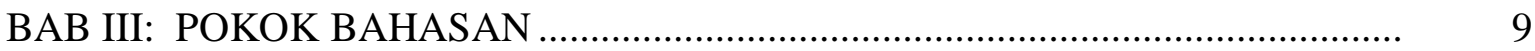

A. MODUL 1: KETERAMPILAN WAWANCARA I ............................. 9

1. Pendahuluan .................................................................... 9

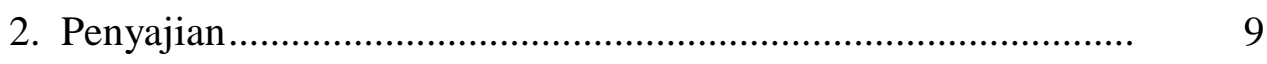

3. Tugas dan Lembar Kerja..................................................... 11

4. Kunci Tugas ....................................................................... 12

5. Referensi ....................................................................... 12

B. MODUL 2: KETERAMPILAN WAWANCARA II........................... 13

1. Pendahuluan ...................................................................... 13

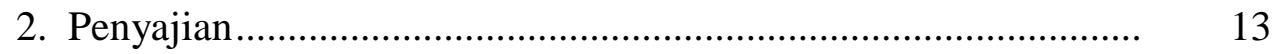

3. Tugas dan Lembar Kerja ........................................................ 14

4. Kunci Tugas ..................................................................... 15

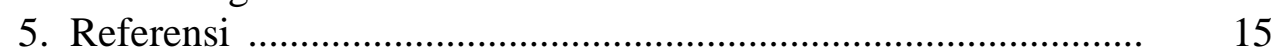

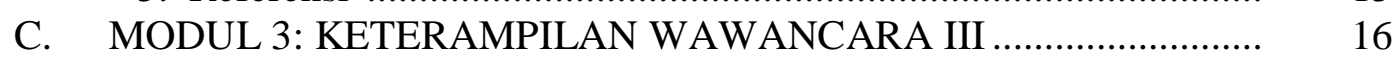

1. Pendahuluan........................................................................... 16

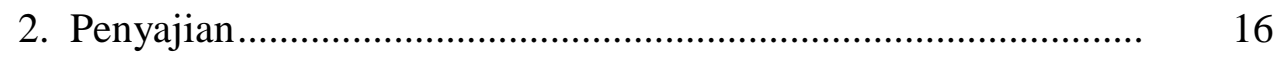

3. Tugas dan Lembar Kerja.................................................... 18

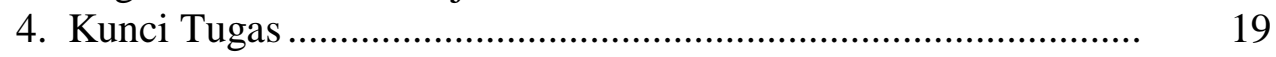

5. Referensi ............................................................................. 19

D. MODUL 4: WAWANCARA SURVEI............................................ 20

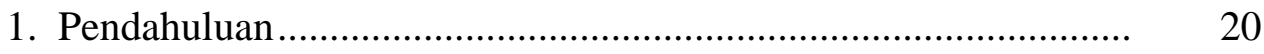

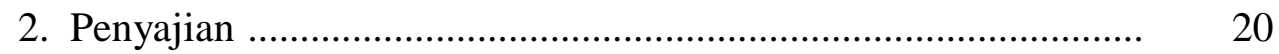

3. Tugas dan Lembar Kerja ....................................................... 21

4. Kunci Tugas ......................................................................... 22

5. Referensi …....................................................... 22

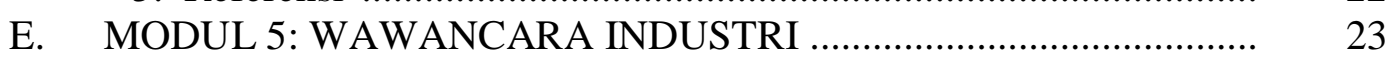

1. Pendahuluan.................................................................... 23

2. Penyajian ........................................................................... 23

3. Tugas dan Lembar Kerja..................................................... 24

4. Kunci Tugas ........................................................................... 25 
5. Referensi ................................................................................. 25

F. MODUL 6: KETERAMPILAN WAWANCARA UNTUK

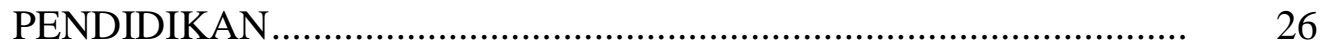

1. Pendahuluan ........................................................................... 26

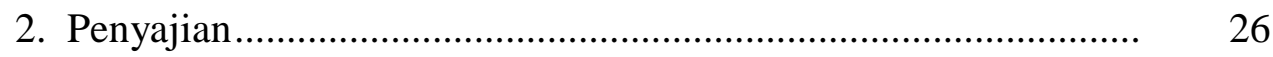

3. Tugas dan Lembar Kerja ...................................................... 28

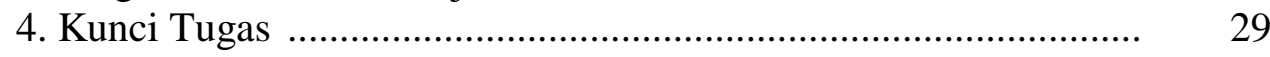

5. Referensi ................................................................................. 29

G. MODUL 7: KETERAMPILAN WAWANCARA UNTUK

KONSELING/ KLINIS ................................................................ $\quad 30$

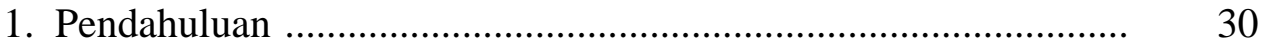

2. Penyajian .......................................................................... $\quad 30$

3. Tugas dan Lembar Kerja ...................................................... 32

4. Kunci Tugas .................................................................... 33

5. Referensi .................................................................................. 33

H. MODUL 8: DISKUSI KELOMPOK TERARAH (DKT) .................... 34

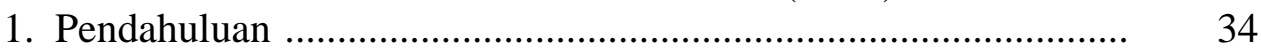

2. Penyajian .......................................................................... 34

3. Tugas dan Lembar Kerja ..................................................... 36

4. Kunci Tugas ..................................................................... 37

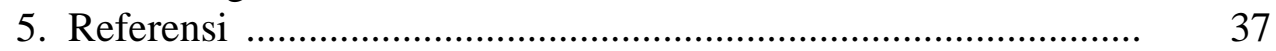

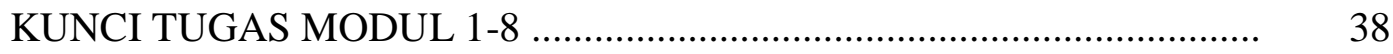

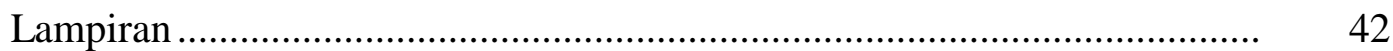




\section{DAFTAR TABEL}

1. Tabel SAP (Satuan Acara Praktikum) Wawancara 


\section{BAB I \\ PENDAHULUAN}

\section{A. PROFIL LABORATORIUM}

Laboratorium wawancara ini digunakan untuk melakukan praktikum wawancara di bidang psikologi industri, pendidikan, sosial, dan klinis. Laboratorium ini ditata secara bervariasi disesuaikan dengan kebutuhan bidang psikologi yang sedang dipraktekkan saat praktikum.

Setiap wawancara memiliki tujuan yang berbeda-beda sehingga membutuhkan penataan ruang laboratorium serta peralatan yang sesuai dengan tujuan tiap wawancara yang dilaksanakan. Setiap mahasiswa berkesempatan untuk memanfaatkan laboratorium seoptimal mungkin, guna mengasah keterampilan wawancara yang dimiliki sehingga mahasiswa semakin piawai melakukan wawancara kepada calon klien yang dihadapi.

\section{VISI:}

Menjadikan laboratorium wawancara sebagai sarana pembelajaran, penelitian, dan pengabdian masyarakat di bidang psikologi ( sosial, industri, pendidikan dan klinis).

\section{MISI:}

1. Menjadi pusat pembelajaran praktis dan eksperimental bagi mahasiswa di bidang psikologi sosial, industri, pendidikan dan klinis.

2. Melaksanakan penelitian dan publikasi karya ilmiah yang bertaraf nasional maupun internasional di bidang psikologi dengan menerapkan keterampilan wawancara sebagai salah satu alat pengumpul data.

3. Menerapkan hasil penelitian dalam bidang psikologi melalui pengabdian kepada masyarakat.

4. Mengembangkan sumber daya laboratorium psikologi secara berkesinambungan, melalui pelatihan-pelatihan yang dapat memperkaya keterampilan wawancara.

\section{B. MANAJEMEN LABORATORIUM}

Laboratorium Wawancara merupakan bagian dari Laboratorium Psikologi secara keseluruhan. Dengan demikian, laboratorium wawancara di bawah pengawasan dan tanggung jawab Kepala Laboratorium Psikologi Fakultas Psikologi. Kepala Laboratorium Psikologi Fakultas Psikologi bertanggung jawab secara langsung kepada Dekan Fakultas Psikologi.

Dalam pelaksanaannya, Kepala Laboratorium Psikologi berkoordinasi dengan Kepala Program Studi Psikologi untuk memenuhi kebutuhan internal, berkenaan dengan pelaksanaan praktikum wawancara, sebagai bagian dari kurikulum yang telah ditetapkan oleh Fakultas. Sedangkan untuk memenuhi kebutuhan eksternal, Kepala Laboratorium Psikologi berkoordinasi dengan Kepala Pusat Pelayanan Psikologi Terapan Umsida. 
Struktur Organisasi Fakultas :

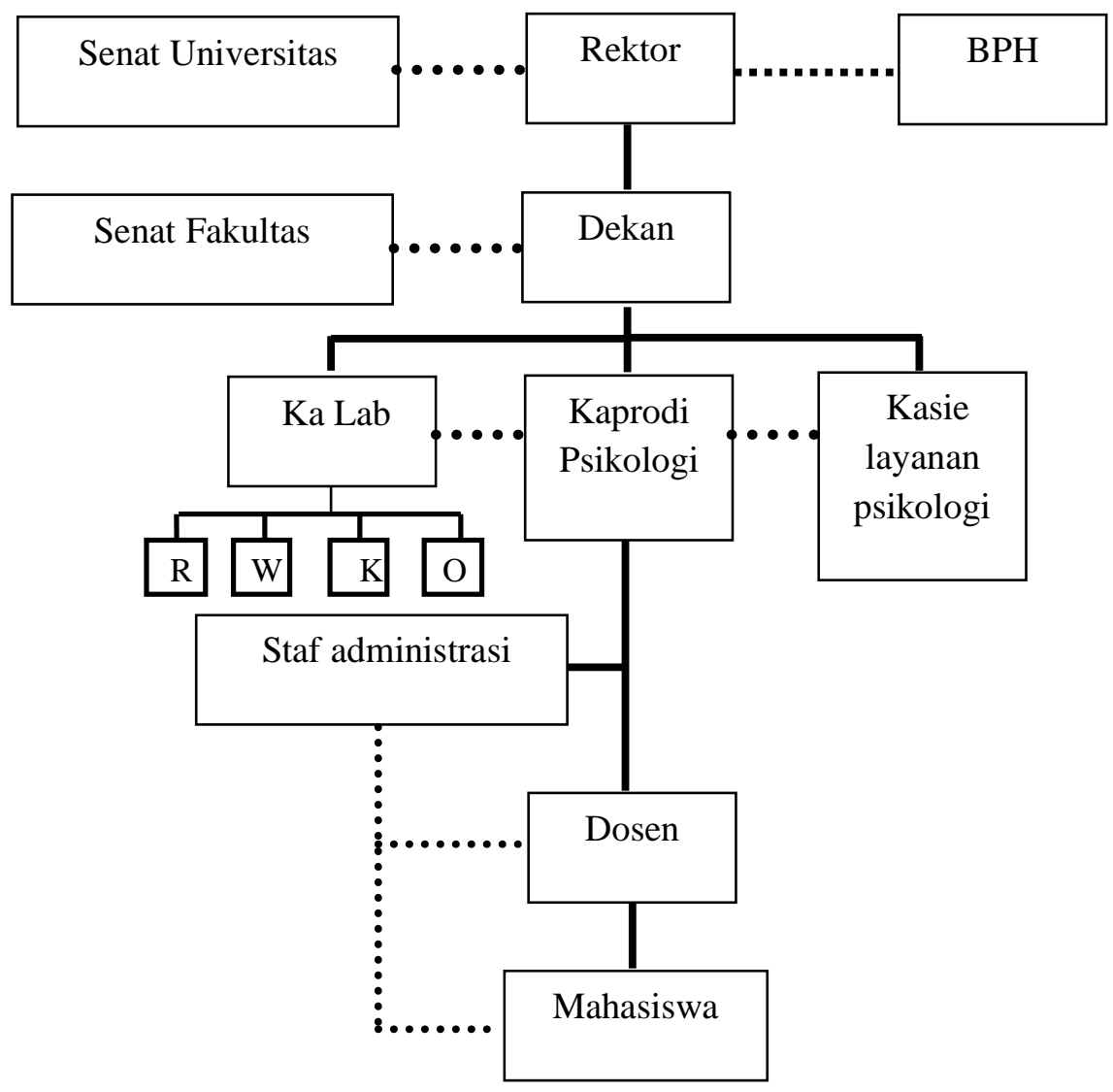

Keterangan :
$=$ Garis isntruktif
$\mathrm{R}=$ Lab. Rorschach
$\mathrm{I}=$ Lab. Interviu
....... = Garis koordinatif
$\mathrm{K}=$ Lab Konseling
$\mathrm{O}=$ Lab. Observasi

\section{PENGGUNAAN LABORATORIUM}

Laboratorium wawancara ini digunakan untuk mahasiswa dalam praktikum wawancara di bidang psikologi industri, pendidikan, sosial, dan klinis.

\section{PERALATAN}

Di laboratorium ini disediakan peralatan yang diperlukan dalam pelaksanaan praktikum wawancara, yaitu meliputi:

1. Papan tulis, digunakan untuk menjelaskan prosedur dalam pelaksanaan wawancara yang akan dilakukan mahasiswa

2. Meja dan kursi, digunakan untuk melakukan praktikum wawancara untuk iter (pewawancara) dan itee (yang diwawancarai) 


\section{E. PERALATAN PENDUKUNG}

Beberapa peralatan yang mendukung pelaksanaan praktikum wawancara dilengkapi pula dalam laboratorium ini yaitu:

1. Alat perekam (tape recorder), digunakan untuk merekam proses wawancara yang berlangsung selama praktikum

2. Alat tulis, digunakan untuk mencatat hal-hal penting bagi iter. 


\section{BAB II}

\section{KURIKULUM}

\section{A. ANALISIS MATERI/INSTRUKSIONAL}

Tujuan instruksional umum yang akan dicapai pada praktikum di laboratorium wawancara adalah:

1. Mahasiswa memahami maksud dan tujuan pelaksanaan wawancara.

2. Mahasiswa dapat mempraktekkan wawancara sesuai pedoman yang diberikan.

3. Mahasiswa dapat menyusun laporan praktikum wawancara yang telah dilakukan.

\section{B. SILABUS PRAKTIK}

Silabus praktik yang ditetapkan untuk praktikum wawancara adalah:

1. Praktek 1:

Keterampilan wawancara I, meliputi:

a. Mempraktekkan macam-macam kalimat tanya utama

b. Mempraktekkan probing

2. Praktek 2:

Keterampilan wawancara II, meliputi:

a. Keterampilan mendengarkan secara kritis

b. Keterampilan mendengarkan secara aktif

c. Keterampilan mendengarkan dengan empati

d. Keterampilan mencatat hasil wawancara

3. Praktek 3:

Keterampilan wawancara III, meliputi:

a. Keterampilan membuka wawancara (opening)

b. Keterampilan dalam wawancara utama (body)

c. Keterampilan menutup wawancara (closing)

4. Praktek 4:

Wawancara survei:

a. Perencanaan wawancara survei

b. Mengawali wawancara survei

c. Pelaksanaan wawancara survei

d. Menutup wawancara survei

e. Membuat laporan wawancara survei

5. Praktek 5:

Wawancara karyawan:

a. Perencanaan wawancara kerja

b. Mengawali wawancara kerja

c. Pelaksanaan wawancara kerja

d. Menutup wawancara kerja

e. Membuat laporan wawancara kerja 
6. Praktek 6:

Wawancara pendidikan:

a. Perencanaan wawancara untuk menemukan problem anak didik

b. Mengawali wawancara untuk menemukan problem anak didik

c. Pelaksanaan wawancara untuk menemukan problem anak didik

d. Menutup wawancara untuk menemukan problem anak didik

e. Membuat laporan wawancara untuk menemukan problem anak didik

7. Praktek 7:

a. Perencanaan wawancara untuk menggali problem klinis individu

b. Mengawali wawancara untuk menggali problem klinis individu

c. Pelaksanaan wawancara untuk menemukan problem anak didik

d. Menutup wawancara untuk menemukan problem anak didik

e. Membuat laporan wawancara untuk menemukan problem anak didik

8. Praktek 8:

a. Perencanaan wawancara kelompok

b. Mengawali wawancara kelompok

c. Pelaksanaan wawancara kelompok

d. Menutup wawancara kelompok

e. Membuat laporan wawancara kelompok

\section{SAP (SATUAN ACARA PRAKTIK)}

Praktikum wawancara ini disusun dalam 7 pertemuan dengan uraian sebagai berikut:

Tabel 1. SAP (Satuan Acara Praktik) Wawancara

\begin{tabular}{|c|c|c|}
\hline $\begin{array}{l}\text { Pertemuan } \\
\text { Ke- }\end{array}$ & Pokok Bahasan & $\begin{array}{c}\text { Tinjauan Intruksional Khusus (TIK) dan } \\
\text { Sasaran Belajar }\end{array}$ \\
\hline 1 & $\begin{array}{l}\text { Keterampilan dasar } \\
\text { wawancara I }\end{array}$ & $\begin{array}{l}\text { TIK : } \\
\text { Mahasiswa memahami dan memiliki } \\
\text { keterampilan yang harus dipenuhi } \\
\text { sebagai iter dalam melakukan } \\
\text { wawancara } \\
\text { Sasaran Belajar: } \\
- \text { Mahasiswa memiliki keterampilan } \\
\text { menyampaikan pertanyaan utama } \\
- \text { Mahasiswa dapat memberikan } \\
\quad \text { probing (inquiry = pertanyaan } \\
\quad \text { tambahan) pada saat yang tepat }\end{array}$ \\
\hline 2 & $\begin{array}{l}\text { Keterampilan dasar } \\
\text { wawancara II }\end{array}$ & $\begin{array}{l}\text { TIK : } \\
\text { Mahasiswa memiliki keterampilan } \\
\text { mendengarkan dalam proses wawancara } \\
\text { Sasaran Belajar: } \\
\text { - Mahasiswa berlatih mendengarkan }\end{array}$ \\
\hline
\end{tabular}




\begin{tabular}{|c|c|c|}
\hline & & $\begin{array}{l}\text { dengan kritis } \\
-\quad \text { Mahasiswa berlatih mendengarkan } \\
\text { dengan aktif } \\
-\quad \text { Mahasiswa berlatih mendengarkan } \\
\text { dengan empati }\end{array}$ \\
\hline 3 & $\begin{array}{l}\text { Penyusunan pedoman } \\
\text { wawancara dan } \\
\text { laporan wawancara }\end{array}$ & $\begin{array}{l}\text { TIK: } \\
\text { Mahasiswa mampu menyusun laporan } \\
\text { wawancara berdasarkan pedoman } \\
\text { wawancara } \\
\text { Sasaran Belajar: } \\
\text { - } \text { Mahasiswa mampu menyusun } \\
\quad \text { pedoman wawancara berdasarkan } \\
\quad \text { fenomena yang akan diwawancarai } \\
\text { - Mahasiswa mampu menyusun } \\
\quad \text { laporan wawancara sesuai format } \\
\quad \text { yang diberikan } \\
\end{array}$ \\
\hline 4 & $\begin{array}{l}\text { Wawancara survei } \\
\text { (sosial) }\end{array}$ & $\begin{array}{l}\text { TIK : } \\
\text { Mahasiswa dapat memahami prosedur } \\
\text { wawancara survei dan menghasilkan } \\
\text { data yang akurat tentang informasi yang } \\
\text { dibutuhkan di area survei } \\
\text { Sasaran Belajar: } \\
\text { - Mahasiswa mampu menentukan } \\
\text { target permasalahan yang digali } \\
\text { dalam survei } \\
\text { - } \text { Mahasiswa mampu menyusun } \\
\text { pedoman wawancara survei sesuai } \\
\text { target permasalahan yang digali } \\
\text { - Mahasiswa mampu mengawali, } \\
\text { melaksanakan dan menutup } \\
\text { wawancara survei } \\
\text { - Mahasiswa mampu menyusun } \\
\text { laporan wawancara berdasarkan } \\
\text { pedoman wawancara }\end{array}$ \\
\hline 5 & Wawancara industri & $\begin{array}{l}\text { TIK : } \\
\text { Mahasiswa dapat memahami prosedur } \\
\text { wawancara dalam industri (kerja) sesuai } \\
\text { kebutuhan informasi yang ingin } \\
\text { diperoleh dan menghasilkan data yang } \\
\text { akurat tentang informasi yang } \\
\text { dibutuhkan di dunia industri } \\
\text { Sasaran Belajar: } \\
\text { - Mampu menentukan target } \\
\text { permasalahan yang digali dalam } \\
\text { wawancara di bidang industri/kerja } \\
- \text { Mahasiswa mampu menyusun } \\
\text { pedoman wawancara di bidang } \\
\text { industri secara umum (kepegawaian }\end{array}$ \\
\hline
\end{tabular}




\begin{tabular}{|c|c|c|}
\hline & & $\begin{array}{l}\text { dan perusahaan) } \\
\text { - } \\
\text { Mahasiswa mampu mengawali, } \\
\text { melaksanakan dan menutup } \\
\text { wawancara di bidang industri } \\
\text { - } \\
\text { Mahasiswa mampu menyusun } \\
\text { laporan wawancara berdasarkan } \\
\text { pedoman wawancara }\end{array}$ \\
\hline 6 & $\begin{array}{l}\text { Wawancara } \\
\text { pendidikan }\end{array}$ & $\begin{array}{l}\text { TIK : } \\
\text { Mahasiswa dapat memahami prosedur } \\
\text { wawancara di bidang pendidikan dan } \\
\text { menghasilkan data yang akurat tentang } \\
\text { problem yang dialami anak didik di } \\
\text { sekolah } \\
\text { Sasaran Belajar : } \\
\text { - Mampu menentukan permasalahan } \\
\quad \text { yang akan digali serta menentukan } \\
\text { sasaran subyek } \\
\text { - Mahasiswa mampu menyusun } \\
\text { pedoman wawancara untuk } \\
\text { menggali permasalahan subyek } \\
\text { hingga terungkap permasalahan } \\
\text { yang sesungguhnya } \\
\text { - Mahasiswa mampu mengawali, } \\
\text { melaksanakan dan menutup } \\
\text { wawancara pendidikan } \\
\text { Mahasiswa mampu menyusun } \\
\text { laporan wawancara berdasarkan } \\
\text { pedoman wawancara }\end{array}$ \\
\hline 7 & Wawancara klinis & $\begin{array}{l}\text { TIK : } \\
\text { Mahasiswa dapat memahami prosedur } \\
\text { wawancara klinis dan menghasilkan } \\
\text { data yang akurat tentang problem klinis } \\
\text { atau gangguan yang dialami subyek } \\
\text { Sasaran Belajar: } \\
\text { - Mampu menentukan target } \\
\text { permasalahan klinis subyek } \\
\text { - Mahasiswa mampu menyusun } \\
\text { pedoman wawancara untuk } \\
\text { menggali permasalahan subyek } \\
\text { hingga terdeteksi gejala-gejala klinis } \\
\text { yang dialami subyek } \\
\text { - Mahasiswa mampu mengawali, } \\
\text { melaksanakan dan menutup } \\
\text { wawancara klinis } \\
\text { - Mahasiswa mampu menyusun } \\
\text { laporan wawancara berdasarkan } \\
\text { pedoman wawancara }\end{array}$ \\
\hline
\end{tabular}




\begin{tabular}{|c|c|c|}
\hline 8 & $\begin{array}{l}\text { Diskusi Kelompok } \\
\text { Terarah }\end{array}$ & $\begin{array}{l}\text { TIK : } \\
\text { Mahasiswa dapat memahami prosedur } \\
\text { diskusi kelompok terarah dan dapat } \\
\text { melakukan diskusi mengumpulkan } \\
\text { pendapat tentang suatu hal atau kasus } \\
\text { tertentu } \\
\text { Sasaran Belajar: } \\
-\quad \text { Mahasiswa mampu menentukan } \\
\text { target permasalahan yang digali } \\
\text { dalam diskusi kelompok terarah } \\
-\quad \text { Mahasiswa mampu mengarahkan } \\
\text { diskusi hingga tercapai tujuan yaitu } \\
\text { mengumpulkan pendapat tentang } \\
\text { suatu hal } \\
\text { - Mahasiswa mampu memerankan } \\
\text { diri sebagai pemandu, notulen, dan } \\
\text { anggota dalam diskusi kelompok } \\
\text { terarah }\end{array}$ \\
\hline
\end{tabular}




\section{BAB III}

\section{POKOK BAHASAN}

Wawancara adalah proses percakapan yang berlangsung secara sistematis dan terorganisasi yang dilakukan oleh pewawancara (iter) dan sejumlah orang responden atau yang diwawancarai (itee) untuk memperoleh informasi tentang suatu hal yang diteliti. Tujuan wawancara adalah untuk mendapatkan informasi yang akurat tentang obyek tertentu. Wawancara dapat dilakukan dalam berbagai setting bidang, yaitu sosial, industri, pendidikan, dan klinis.

Dalam modul praktikum ini mahasiswa diajak mempraktekkan wawancara terkait empat bidang di atas agar memiliki wacana dan pengalaman sehingga lebih siap terjun ke masyarakat dengan mempraktekkan keterampilan wawancara yang telah diterimanya. Titik tekan keempat bidang itu berbeda-beda, sehingga perlu dipraktekkan satu demi satu agar semakin menguasai keterempilan wawancara dengan baik.

Bidang sosial menitikberatkan pada menemukan fenomena yang terjadi di masyarakat, penyebab, dan dampak yang ditimbulkan bagi masyarakat. Bidang industri memfokuskan pada kehidupan dunia kerja, dapat berkaitan dengan rekruitmen, seleksi, promosi, kepuasan kerja, atau kinerja karyawan di suatu perusahaan. Bidang pendidikan, lebih fokus untuk menemukan permasalahan yang terjadi pada peserta didik, dan di bidang klinis bertujuan untuk mengetahui gejala-gejala klinis yang mungkin muncul pada individu.

\section{A. MODUL 1: Keterampilan Wawancara I}

\section{Pendahuluan}

Wawancara merupakan suatu proses interaksi dan komunikasi. Dalam proses ini, hasil wawancara ditentukan oleh beberapa faktor yang berinteraksi yaitu iter, itee, tema, dan situasi wawancara.

Pelaksanaan wawancara dapat berhasil sangat ditentukan oleh keterampilan pewawancara (iter) dalam bertanya dan mendengarkan. Kedua aktivitas ini perlu dilatihkan agar mahasiswa terbiasa memberikan pertanyaan-pertanyaan yang berbobot sesuai informasi yang dibutuhkannya dan dapat mendengarkan informasi yang diterimanya dengan baik.

Syarat menjadi iter yang baik ialah keterampilan mewawancarai, motivasi yang tinggi,dan rasa aman, artinya tidak ragu dan takut dalam menyampaikan pertanyaan. Hal ini dapat mempengaruhi hasil wawancara dan mutu jawaban yang diberikan itee ditentukan oleh kemampuan itee menangkap isi pertanyaan dengan tepat serta bersedia menjawabnya dengan baik.

Iter diharapkan dapat menyampaikan pertanyaan kepada itee, dan merangsang itee untuk menjawabnya. Semakin terampil iter bertanya maka iter mampu menggali informasi yang semakin mendalam, untuk kemudian dicatat.

\section{Penyajian (Tutorial)}

\section{a. Tujuan}

Tujuan materi ini adalah mahasiswa memahami tipe-tipe pertanyaan yang dapat diberikan kepada itee agar terampil dalam menggali informasi dari itee. 


\section{b. Materi}

Terdapat dua tipe pertanyaan berdasarkan cara menyampaikannya:

a. Pertanyaan terbuka, yaitu pertanyaan yang bersifat luas, tidak terbatas lingkup dan arah, sehingga informasi yang diperoleh lebih banyak. Cara menyampaikan pertanyaan terbuka yaitu dengan:

1) Menciptakan rapport, percakapan yang berkesinambungan

2) Diawali dengan 5W (lima kata tanya: what, where, why, who, when dan ceritakan tentang....

3) Gambarkan .... dengan cara apa ....

4) Menggabungkan opini, sudut pandang, pikiran dan perasaan

b. Pertanyaan tertutup, yaitu pertanyaan yang bersifat terbatas, jawaban atas pertanyaan sangat sempit dan mengarah namun tidak selalu dangkal. Cara menyampaikan pertanyaan tertutup yaitu:

1) Mengembangkan penggalian fakta

2) Diawali dengan kata tanya: mampukah, sudahkah, bisakah, apakah

3) Membatasi percakapan dan jawaban ( itee menjawab "Ya" atau "Tidak"), sehingga seperti tanya jawab bukan percakapan

4) Iter lebih banyak bicara

Pertanyaan tertutup dibagi menjadi 2, yaitu:

a. Pertanyaan tertutup dengan alternatif jawaban lebih dari satu

b. Pertanyaan tertutup dengan dua alternatif jawaban: Ya/Tidak, Penting/Tidak

Penggolongan susunan pertanyaan berdasarkan informasi yang dibutuhkan, meliputi:

a. Pertanyaan Primer, ialah pertanyaan dasar yang diberikan untuk mengawali suatu topik pembicaraan dengan itee.

Contoh: Apa yang Anda rasakan saat ini?

b. Pertanyaan Sekunder, ialah pertanyaan lanjutan yang mengikuti pertanyaan primer dalam upaya untuk mendapatkan informasi lebih lanjut dari itee.

Pertanyaan sekunder disebut pula sebagai probing atau follow up question. Jenisjenis probing yaitu:

1. Silent probes, yaitu respon yang diberikan dengan bahasa non verbal supaya itee melanjutkan pembicaraannya.

Misal: anggukan, persilahkan dengan tangan, Ooo...

2. Nudging probes, yaitu memberikan respon dengan kata atau frase

Misal: lalu? Jadi? Teruskan, apa yg terjadi kemudian? Bagaimana respon anda? Mengapa?

3. Clearinghouse probes, yaitu kalimat yang diberikan untuk meminta konfirmasi kepada itee jika ada hal yang tertinggal atau ingin disampaikan kembali agar lebih jelas

Misal: sebelum pindah ke topik lain, masih ada hal penting yang belum dijelaskan?

4. Informational probes yaitu pernyataan untuk minta kejelasan terhadap:

a. Jawaban yang dangkal,

Misal: katakan lebih lanjut tentang...

b. Jawaban masih membingungkan, 
Misal: tolong definisikan tentang "kepo"

c. Jawaban mengandung perasaan/sikap tertentu,

Misal: mengapa anda merasa begitu?

bagaimana anda menyikapi kemarahan orang tua?

5. Restatement probes yaitu kalimat tanya sekunder yg baru untuk meminta itee melanjutkan pembicaraan karena itee belum penuh dalam memberikan jawaban.

Misal: Tadi anda baru saja cerita kondisi ibu anda, bagaimana kondisi ayah anda setelah mereka bercerai?

6. Reflective probes, yaitu kalimat tanya yang berupa pengertian sendiri

Misal: maksud anda teman sejati adalah teman yg menerima apa adanya?

7. Mirror probes yaitu kalimat persis sama dengan yang disampaikan itee sebelumnya, dengan harapan itee melanjutkan pembicaraannya.

Misal: itee: Bersyukur sekali saat itu ada orang yang menolong

Iter: Bersyukur sekali saat itu ada orang yang menolong

\section{c. Metode}

Metode praktikum yang digunakan adalah simulasi dengan teman

\section{d. Instrumen}

1. Ruangan

2. Meja dan Kursi

3. Alat perekam

4. Alat tulis

\section{e. Prosedur}

1. Mahasiswa diberikan instruksi untuk melakukan simulasi wawancara sesuai dengan tema masing - masing

2. Mahasiswa diminta mencari pasangan untuk diwawancarai

3. Mahasiswa diminta mencatat semua data yang diperolehnya

4. Itee diminta mencatat kekurangan dan kelebihan iter

5. Membuat laporan hasil wawancara

6. Seminar / presentasi hasil praktikum

\section{Tugas dan Lembar Kerja}

1. Buatlah pertanyaan dengan diawali $5 \mathrm{~W}+1 \mathrm{H}$

2. Apa hal-hal yang harus diperhatikan dalam menyusun pertanyaan?

3. Apakah nudging probes itu?

4. Apakah pertanyaan terbuka itu?

5. Sebutkan penggolongan susunan pertanyaan berdasarkan informasi yang dibutuhkan

6. Apakah pertanyaan tertutup itu?

Lembar Kerja: dilakukan berdasarkan prosedur praktikum 


\section{FORMAT LAPORAN PRAKTIKUM \\ KETERAMPILAN WAWANCARA I}
I. Cover
II. Tujuan Wawancara
III. Pedoman Wawancara
IV. Hasil Wawancara

\begin{tabular}{|l|c|c|c|c|}
\hline \multirow{2}{*}{ Verbatim } & \multicolumn{4}{|c|}{ Body } \\
\cline { 2 - 5 } & $\begin{array}{c}\text { Tipe } \\
\text { Pertanyaan }\end{array}$ & Probing & $\begin{array}{c}\text { Penggunaan } \\
\text { bahasa }\end{array}$ & $\begin{array}{c}\text { Kesalahan } \\
\text { wawancara }\end{array}$ \\
\hline & & & & \\
\hline & & & & \\
\hline & & & & \\
\hline & & & & \\
\hline & & & & \\
\hline
\end{tabular}

V.Kesimpulan

Sidoarjo, 2016

Tanda tangan

Nama Lengkap

$\mathrm{Nim}$

\section{Kunci Tugas}

Lihat halaman 38 - 41

\section{Referensi}

1. Effendi, S dan Tukiran. 2012. Metode Penelitian Survei. Jakarta: LP3ES

2. Satori, D. dan Komariah, A. 2010. Metodologi Penelitian Kualitatif. Bandung: Alfabeta

3. Gorden, R.L. 2008. Basic Interviewing Skills. Illinois: F.E. Peacock Publishers, Inc. 


\section{B. MODUL 2: KETERAMPILAN WAWANCARA II}

\section{Pendahuluan}

Keterampilan mendengarkan memiliki peranan yang sama pentingnya dengan keterampilan bertanya dalam menunjang keberhasilan suatu wawancara. Menjadi pendengar yang baik berarti bebas dari kecemasan sendiri dan memberi itee perhatian yang penuh (tentang hal yang disampaikan itee, cara itee menyampaikan, intonasi, ekspresi, dan sikap tubuh).

Selain penuh perhatian kepada itee, juga pada diri sendiri. Ketika wawancara berlangsung, iter perlu sadar akan kebutuhan, nilai, dan standar pribadinya. Hendaknya iter memeriksa bagaimana hal-hal tersebut dapat mempengaruhi teknik wawancara dan hipotesis yang dibentuk oleh iter mengenai itee. Iter harus menyadari bahwa standar pribadi iter dapat mempengaruhi keputusan/kesimpulan yang dibuat tentang itee.

\section{Penyajian}

\section{a. Tujuan}

Tujuan materi ini adalah mahasiswa memahami dan dapat mempraktekkan cara mendengarkan dengan kritis, aktif, dan dengan empati.

\section{b. Materi}

Tiga macam mendengarkan, yaitu:

1. Critical listening (mendengarkan dengan kritis)

2. Active listening (mendengarkan dengan aktif)

3. Empathic listening (mendengarkan dengan empati)

1. Critical Listening (mendengarkan dengan kritis) meliputi:

- Menangkap informasi secara pasif

- Sangat sedikit feedback (umpan balik) terhadap itee

- Mencoba mencari topik/isi pembicaraan untuk kepentingan sendiri

- Diam dan berusaha mendebat pada saat tertentu

2. Active Listening (mendengarkan aktif) meliputi:

- Berusaha memahami dan memberikan feedback (umpan balik) langsung

- Siap dengan pesan verbal dan nonverbal untuk membangun mutual understanding

- Menunjukkan ketertarikan, pengertian, dan feedback yang tepat

- Mendengarkan secara mendalam dan terlibat aktif selama proses wawancara

3. Empathic Listening (Mendengarkan dengan empati)

- Memberikan respon dengan menunjukkan bahwa iter memahami apa yang terjadi/dialami oleh itee. Ekspresi pemahaman sangat penting.

- Itee bisa merasakan bahwa iter mengenali dan memahami situasi yang menimpanya. 
- Respon menyeluruh: memberi keyakinan, kenyamanan, dan menunjukkan kehangatan.

- Diperlukan dalam menghadapi masalah emosi dan personal.

Contoh:

1. Marah atau denial

itee: "Harusnya aku tidak bertindak seburuk itu"

iter: "Saya paham Anda marah; tidak adil membandingkan orang per orang ya..."

2. Kecewa

itee: "Saya nggak percaya..."

iter: "Ya, sangat sulit untuk percaya bahwa..."

3. Misunderstanding

iter: "Ia nggak pernah mau mendengarkan saya"

itee: "Kita semua merasa begitu"

4. Mengasihani diri sendiri

itee: "Saya nggak pernah melakukan sesuatu dengan benar"

iter: "Apakah situasinya begitu buruk? "

\section{c. Metode}

Metode yang digunakan dalam praktikum ini adalah simulasi dengan teman

\section{d. Instrumen}

1. Ruangan

2. Meja dan Kursi

3. Alat tulis

4. Alat perekam

\section{e. Prosedur}

1. Mahasiswa diberikan instruksi untuk melakukan simulasi wawancara sesuai dengan tema masing - masing.

2. Mahasiswa diminta mencari pasangan untuk diwawancarai

3. Mahasiswa diminta mencatat semua data yang diperolehnya

4. Itee diminta mencatat kekurangan dan kelebihan iter

5. Membuat laporan hasil wawancara

6. Seminar / presentasi hasil praktikum.

\section{Tugas dan Lembar Kerja}

1. Apa yang perlu diperhatikan dalam active listening ?

2. Apa yang perlu diperhatikan dalam emphatic listening?

3. Apa obyek observasi non-verbal ketika wawancara?

4. Jelaskan fungsi active listening tentang memberikan respon

Lembar kerja: dikerjakan sesuai prosedur praktikum 


\section{FORMAT LAPORAN PRAKTIKUM WAWANCARA \\ KETARAMPILAN WAWANCARA II}

I. Cover

II. Tujuan Wawancara

III. Pedoman Wawancara

IV. Hasil Wawancara

\begin{tabular}{|c|c|c|c|c|c|c|}
\hline \multirow[b]{2}{*}{ Verbatim } & \multicolumn{4}{|c|}{ Body } & \multirow[b]{2}{*}{$\begin{array}{l}\text { Emphatic } \\
\text { Listening }\end{array}$} & \multirow[b]{2}{*}{$\begin{array}{c}\text { Opening/ } \\
\text { Closing }\end{array}$} \\
\hline & $\begin{array}{c}\text { Pertanyaan } \\
\text { Primer }\end{array}$ & Probing & $\begin{array}{l}\text { Critical } \\
\text { listening }\end{array}$ & $\begin{array}{c}\text { Active } \\
\text { Listening }\end{array}$ & & \\
\hline & & & & & & \\
\hline & & & & & & \\
\hline & & & & & & \\
\hline & & & & & & \\
\hline & & & & & & \\
\hline
\end{tabular}

V. Kesimpulan

Sidoarjo 2016

Tanda tangan

Nama Lengkap

$\mathrm{Nim}$

\section{Kunci Tugas}

Lihat di halaman 38 - 41

\section{Referensi}

1. Effendi, S dan Tukiran. 2012. Metode Penelitian Survei. Jakarta: LP3ES

2. Satori, D. Dan Komariah, A. 2010. Metodologi Penelitian Kualitatif. Bandung: Alfabeta

3. Gorden, R.L. 2008. Basic Interviewing Skills. Illinois: F.E. Peacock Publishers, Inc. 


\section{MODUL 3 : KETERAMPILAN WAWANCARA III}

\section{Pendahuluan}

Interview atau wawancara adalah suatu proses komunikasi interaksional antara dua pihak. Cara pertukaran yang digunakan adalah cara verbal dan nonverbal, dan mempunyai tujuan tertentu yang spesifik.

Ketika melakukan wawancara, seorang pewawancara (iter) biasanya bertemu untuk pertama kalinya dengan yang diwawancarai, dan pewawancara akan memberikan kesan awal pada orang yang diwawancarai (itee). Ketika wawancara berlangsung, kesan lain akan terbentuk dan kesan awal akan dimodifikasi berdasarkan hubungan yang sedang berjalan. Oleh karena itu, diperlukan keterampilan wawancara yang baik, agar data yang diperoleh lebih lengkap dan akurat.

\section{Penyajian}

\section{a. Tujuan}

Tujuan penyajian materi ini adalah agar mahasiswa memiliki keterampilan dasar dalam melakukan wawancara sehingga dapat melakukan wawancara dengan baik mulai dari pembukaan (opening), materi utama (body), dan penutup (closing).

\section{b. Materi}

Beberapa keterampilan dasar wawancara yang harus dikuasi oleh mahasiswa adalah sebagai berikut:

\section{Tahap Pembukaan (Opening)}

- Langkah pertama : Membangun rapport

1. Perkenalan

2. Mengucap salam

3. Aktivitas non verbal

4. Percakapan topik umum dan ringan

5. Personal inquiry

- Langkah kedua : Orientasi

1. Tujuan

2. Lama dan sifat wawancara

3. Tanggung jawab

4. Manfaat informasi

5. Latar belakang kedatangan itee

\section{Tahap Materi Utama (Body)}

1. Panduan Wawancara:

a. Mengembangkan area inquiry

b. Mengingat jawaban itee

c. Mengenali jawaban yang relevan dan tidak

d. Menentukan pertanyaan lanjutan yang akan dikemukakan 
2. Rencana Wawancara

a. Non scheduled interview

Memiliki panduan atau hanya daftar topik / sub topik

b. Moderately scheduled interview

Terdiri dari pertanyaan secara garis besar dan pertanyaan untuk probing

c. Highly scheduled interview

Memuat seluruh pertanyaan dan penggunaan bahasa/pilihan kata dan kalimat

d. Highly standardized scheduled interview

Seluruh pertanyaan dan jawaban telah tersedia, yang bersifat serupa

\section{Tahap Penutup (Closing)}

Fungsi Closing :

1. Pesan mengakhiri wawancara tetapi tidak mengakhiri hubungan

2. Wawancara diakhiri dengan baik

3. Menyimpulkan materi wawancara

Panduan Closing :

1. Bersikap tulus \& jujur

2. Tidak tergesa - gesa

3. Tidak Memulai topik baru

4. Akhiri tepat pada waktunya

5. Hindari kesalahan menutup wawancara

6. Terbuka tentang rencana selanjutnya

Teknik Verbal dalam Closing

1. Menawarkan untuk menjawab pertanyaan

2. Sampaikan tujuan telah tercapai

3. Buatlah "personal inquiries"

4. Buatlah "professional inquiries"

5. Sampaikan bahwa waktu habis

6. Jelaskan alasan wawancara disudahi

7. Tunjukkan penghargaan dan rasa puas

8. Tunjukan perhatian

9. Buat rencana pertemuan selanjutnya, jika diperlukan

10. Merangkum proses wawancara

Teknik Non Verbal dalam closing

1. Bersandar ke depan

2. Bergerak menjauhi itee

3. Berdiri

4. Melepas silangan tangan

5. Menaruh tangan di atas paha

6. Mengajak berjabat tangan

7. Melirik jam 


\section{c. Instrumen}

1. Ruangan

2. Meja dan Kursi

3. Alat tulis

4. Alat perekam

\section{d. Metode}

Dalam praktikum ini metode yang digunakan adalah simulasi dengan teman

\section{e. Prosedur}

1. Mahasiswa diberikan instruksi untuk melakukan simulasi wawancara sesuai dengan tema masing - masing.

2. Mahasiswa diminta mencari pasangan untuk diwawancarai

3. Mahasiswa diminta mencatat semua data yang diperolehnya

4. Itee diminta mencatat kekurangan dan kelebihan iter (pewawancara)

5. Membuat laporan hasil wawancara (format laporan dalam lampiran III)

6. Seminar / presentasi hasil praktikum.

\section{Tugas dan Lembar Kerja}

1. Apa langkah pertama dalam pembukaan wawancara?

2. Sebutkan dan jelaskan satu rencana wawancara

3. Apa fungsi closing dalam wawancara?

4. Sebutkan teknik closing non-verbal dalam wawancara

Lembar kerja: dikerjakan berdasarkan prosedur praktikum

\section{FORMAT LAPORAN PRAKTIKUM WAWANCARA KETARAMPILAN WAWANCARA III}

I. Cover

II. Tujuan Wawancara

III. Pedoman Wawancara

IV. Hasil Wawancara

\begin{tabular}{|c|c|c|c|c|c|c|}
\hline \multirow[b]{2}{*}{ Verbatim } & \multicolumn{4}{|c|}{ Body } & \multirow[b]{2}{*}{ Opening } & \multirow[b]{2}{*}{ Closing } \\
\hline & $\begin{array}{c}\text { Pertanyaan } \\
\text { Primer }\end{array}$ & Probing & Respon & Listening & & \\
\hline & & & & & & \\
\hline & & & & & & \\
\hline & & & & & & \\
\hline & & & & & & \\
\hline & & & & & & \\
\hline
\end{tabular}


V. Kesimpulan

Sidoarjo, 2016

Tanda tangan

Nama Lengkap

Nim

\section{Kunci Tugas}

Lihat di halaman 38 - 41

\section{Referensi}

1. Effendi, S dan Tukiran. 2012. Metode Penelitian Survei. Jakarta: LP3ES

2. Satori, D. Dan Komariah, A. 2010. Metodologi Penelitian Kualitatif. Bandung: Alfabeta

3. Gorden, R.L. 2008. Basic Inter viewing Skills. Illinois: F.E. Peacock Publishers, Inc. 


\section{MODUL 4: KETERAMPILAN WAWANCARA UNTUK SURVEI}

\section{Pendahuluan}

Survei biasanya dilakukan untuk mengumpulkan suatu informasi tentang suatu hal, misalnya persepsi masyarakat terhadap pelaksanaan Pemilu, tingkat loyalitas pelanggan terhadap produk tertentu, atau pendapat mahasiswa tentang kebijakan tertentu universitas. Namun sejauhmana wawancara dan survei dapat dilaksanakan dengan benar dan tepat.

Survei adalah suatu teknik mengumpulkan informasi dari responden dengan cara menanyakan sejumlah pertanyaan terstruktur kepada responden. Kunci dari pengumpulan informasi adalah pada kualitas informasi yang dikumpulkan. Pewawancara memiliki tugas pokok untuk membuat responden dapat berpartisipasi dalam survei dan mencatat informasi dari responden. Sedangkan wawancara adalah sebuah cara yang khusus dalam setting percakapan yang terstruktur, yang masing - masing pewawancara dan responden memiliki batasan peran yang dimainkan.

\section{Penyajian}

\section{a. Tujuan}

Tujuan materi ini adalah mahasiswa memahami dan dapat mempraktekkan wawancara survei pada suatu kasus.

\section{b. Materi}

\section{Teknik Wawancara Umum untuk Survei}

Suksesnya wawancara tergantung dari banyak hal, antara lain tingkat sensibilitas, taktik, kiat, kemampuan hubungan personal, kepribadian dan pemahaman terhadap prosedur yang telah ditetapkan sebelumnya.

Langkah-langkah teknik wawancara survei:

1. Membangun hubungan baik dengan responden. Iter membuat responden dapat merasa terbantu untuk membuat perannya, dapat memahami instruksi yang diberikan secara jelas, memperkuat kinerja, dan menyiapkan sikap yang ramah dan bersahabat serta masih dalam batas interaksi sosial yang profesional.

2. Mempertahankan kenetralan. Iter bersikap obyektif, dan profesional, karena sikap iter akan mempengaruhi persepsi responden mengenai sebuah pertanyaan.

3. Mempertahankan diri dan menjelaskan tujuan survei. Kehadiran iter pertama kali dengan calon responden adalah tugas yang tidak ringan karena saat itulah kontrak pertama kali untuk berinteraksi dengan responden.

4. Mengajak responden bekerjasama. Iter peka terhadap situasi wawancara, melakukan pendekatan manusiawi, melalui sikap empati dan segera menyesuaikan diri dengan responden dan dapat menerima sebagaimana adanya.

5. Probing adalah teknik yang digunakan oleh iter untuk merangsang pikiran responden sehingga memperoleh informasi lebih banyak. Iter harus mampu 
komunikatif, rileks, interaktif, hangat dan kritis tetapi tidak memojokkan respondon dan tidak bernada interogatif.

6. Mencatat hasil wawancara. Suatu pengisian kuesioner yang baik harus hanya mencatat apa yang disampaikan responden, tidak menafsirkan jawaban, dengan catatan diharapkan mewakili suatu gambaran tentang apa yang dikatakan responden dan bagaimana ia mengatakannya.

Langkah - langkah melakukan wawancara survei:

a. Menetapkan tujuan

b. Mencari topik penelitian

c. Menyusun wawancara

d. Mengembangkan pertanyaan

e. Memilih itee

f. Melakukan penelitian

g. Analisis hasil wawancara

\section{c. Instrumen}

1. Ruangan

2. Meja dan Kursi

3. Alat tulis

4. Alat perekam

\section{d. Metode}

Metode yang digunakan dalam praktikum ini adalah melakukan survei ke lapangan sesuai dengan tema-tema tertentu

\section{e. Prosedur}

1. Mahasiswa diberikan tema tertentu untuk melakukan survei

2. Mahasiswa diminta membuat panduan wawancara survei (contoh panduan wawancara survei sebagaimana yang pernah dibaca di skripsi)

3. Mahasiswa survei ke lapangan sesuai tema masing - masing

4. Mahasiswa diminta mencatat semua data yang diperolehnya

5. Membuat laporan wawancara survei

\section{Tugas dan Lembar Kerja}

1. Apakah wawancara survei itu?

2. Apa langkah-langkah wawancara survei?

3. Apa yang harus dilakukan iter agar itee bisa bekerjasama?

Lembar Kerja: dikerjakan berdasarkan prosedur 


\section{FORMAT PRAKTIKUM WAWANCARA \\ WAWANCARA SURVEI}

$\begin{array}{ll}\text { I. } & \text { Cover } \\ \text { II. } & \text { Pendekatan Konseptual } \\ \text { III. } & \text { Pedoman Wawancara } \\ \text { IV. } & \text { Hasil Wawancara Survei }\end{array}$

\begin{tabular}{|l|l|l|l|l|l|}
\hline \multirow{2}{*}{ Verbatim } & \multicolumn{4}{|c|}{ Body } & \multirow{2}{*}{ Opening/Closing } \\
\cline { 2 - 6 } & Fenomena & $\begin{array}{c}\text { Pertanyaan } \\
\text { Primer }\end{array}$ & Probing & Kesalahan & \\
\hline & & & & & \\
\hline & & & & & \\
\hline & & & & & \\
\hline & & & & & \\
\hline & & & & & \\
\hline
\end{tabular}

V. Kesimpulan

Sidoarjo 2016

Tanda tangan

Nama Lengkap

NIM

\section{Kunci Tugas}

Lihat halaman $38-41$

\section{Referensi}

1. Gorden, R.L. 2008. Basic Inter viewing Skills. Illinois: F.E. Peacock Publishers, Inc.

2. Basrowi dan Suwandi. 2008. Memahami Penelitian Kualitatif. Jakarta: Rineka Cipta.

3. Silalahi,U. 2010. Metode Penelitian Sosial. Bandung: Refika Aditama. 


\section{E. MODUL 5: KETERAMPILAN WAWANCARA INDUSTRI}

\section{Pendahuluan}

Wawancara dalam psikologi industri dilakukan saat proses seleksi, sesudah psikotes, pengukuran kinerja, penelurusan motivasi kerja, penelitian kepuasan kerja, pemantauan pelaksanaan kesehatan dan keselamatan kerja, pemeriksaan masalah terkait kinerja seperti stres kerja dan konflik di tempat kerja.

\section{Penyajian (tutorial)}

\section{a. Tujuan}

Tujuan materi ini adalah mahasiswa memahami dan mampu mempraktekkan keterampilan wawancara di bidang industri, serta mampu menentukan area bidang industri.

\section{b. Materi}

Dalam wawancara industri terdapat banyak hal yang dapat disampaikan terutama pada wawancara seleksi yang bertujuan untuk menggali ketepatan hasil dari psikotes dengan kondisi individu yang sebenarnya.

\section{Contoh Pedoman Wawancara Seleksi Kerja}

\section{a. Memilih Pekerjaan}

1. Mengapa saudara memilih pekerjaan ini?

a. Karena tertarik, atau adanya minat.

b. Melihat kemungkinan - kemungkinan yang dapat tercapai

c. Atas nasihat guru/dosen, orang tua, teman atau seseorang

d. Sebab - sebab lain

2. Bagi saudara, apakah yang menyenangkan atau menarik dalam pekerjaan ini?

Dan apa yang kurang menyenangkan atau kurang menarik? Mengapa?

3. Seandainya jaminan kurang memuaskan, apakah saudara akan tetap memilih pekerjaan tersebut?

Ya : mengapa?

Tidak : mengapa?

\section{b. Macam Pekerjaan}

1. Bagaimana pendapat saudara tentang pekerjaan yang paling saudara sukai?

2. Senangkah saudara akan pekerjaan yang selalu harus dikerjakan dengan cara tetap?

3. Saudara lebih suka bekerja dibawah perintah orang lain yang harus saudara turuti, atau memakai cara sendiri?

4. Saudara lebih suka bekerja di dalam atau di luar kantor? Mengapa?

5. Saudara lebih suka bekerja pada bidang yang sama atau berpindah pindah? 
6. Senangkah saudara bekerja bersama orang lain dalam satu ruangan, ataukah lebih senang bekerja sendiri dalam satu ruangan?

7. Apakah saudara merasa masih perlu belajar banyak pada bidang yang akan saudara tekuni?

8. Dapatkah saudara bekerja dengan baik jika ada orang lain yang memperhatikan kerja saudara?

9. Dalam mengerjakan sesuatu perintah, saudara lebih senang berpegang pada peraturan yang sudah ditentukan (SOP) ataukah mencoba mengerjakan dengan cara saudara sendiri?

10. Dapatkah saudara bekerja lama tanpa bersitirahat? Saudara lebih senang beberapa kali beristirahat sebentar, ataukah sesudah bekerja lama lalu beristirahat?

\section{c. Instrumen}
1. Alat tulis
2. Alat perekam
3. Ruangan
4. Meja dan Kursi

\section{d. Metode}

Metode praktikum yang digunakan adalah dengan melakukan wawancara kepada individu yang bekerja di suatu perusahaan (negeri/swasta), sebagai staf, manajer, atau pimpinan

\section{e. Prosedur}

1. Mahasiswa menentukan tema tertentu untuk melakukan wawancara

2. Mahasiswa diminta membuat pedoman wawancara industri sesuai tema

3. Mahasiswa menentukan itee tema masing - masing

4. Mahasiswa diminta mencatat semua data yang diperoleh

\section{Tugas dan lembar kerja}

1. Bagaimana wawancara untuk mengetahui minat pekerjaan?

2. Bagaimana wawancara untuk mengetahui seseorang mencari hiburan di waktu luang?

3. Bagaimana wawancara untuk mengetahui kinerja seseorang?

Lembar Kerja: dikerjakan berdasarkan prosedur praktikum 


\section{FORMAT LAPORAN PRAKTIKUM WAWANCARA \\ INDIVIDUAL UNTUK INDUSTRI}

I. Cover

II. Tujuan Wawancara

III. Job Description

IV. Pedoman Wawancara

V. Hasil Wawancara

\begin{tabular}{|l|l|l|l|l|l|}
\hline \multirow{2}{*}{ Verbatim } & \multicolumn{4}{|c|}{ Body } & \multirow{2}{*}{ Opening/Closing } \\
\cline { 2 - 6 } & Fenomena & $\begin{array}{c}\text { Pertanyaan } \\
\text { Primer }\end{array}$ & Probing & Kesalahan & \\
\hline & & & & & \\
\hline & & & & & \\
\hline & & & & & \\
\hline & & & & & \\
\hline
\end{tabular}

VI. Kesimpulan

Sidoarjo, 2016

Tanda tangan

Nama Lengkap

$\mathrm{Nim}$

\section{Kunci Tugas}

Lihat halaman 38 - 41

\section{Referensi}

1. Balgies, S. 2011. Wawancara Teori dan Aplikasi dalam Psikodiagnostik. Surabaya: IAIN Sunan Ampel Press

2. Basrowi dan Suwandi. 2008. Memahami Penelitian Kualitatif. Jakarta: Rineka Cipta. 


\section{F. MODUL 6: KETERAMPILAN WAWANCARA UNTUK PENDIDIKAN}

\section{Pendahuluan}

Wawancara dalam psikologi pendidikan dilakukan menjelang persiapan seorang individu masuk jenjang pendidikan tertentu, penelusuran masalah - masalah terkait belajar dan proses pembelajaran di sekolah. Guru menjalankan beragam peran di sekolah: sebagai pakar mata pelajaran yang diampu, tutor, konsultan, manajer perilaku, konselor, mediator, dan evaluator. Lebih dari semua itu para guru adalah pengambil keputusan.

\section{Penyajian (Tutorial)}

\section{a. Tujuan}

Tujuan praktikum ini adalah mahasiswa memahami dan mampu mempraktekkan wawancara pendidikan, serta mampu menetapkan area permasalahan dalam wawancara pendidikan.

\section{b. Materi}

Sehari-hari di ruang lingkup sekolah tidak pernah lepas dari permasalahan siswa. Guru memantau perkembangan siswa dalam suatu periode tertentu, misalnya tengah semestar atau akhir semester. Jika dalam pemantauan tersebut guru menilai bahwa seseorang siswa perlu mengikuti konseling dengan psikolog maka perlu ada wawancara pendahuluan dari guru bimbingan karir atau bimbingan konseling di sekolah, jika permasalahan siswa membutuhkan penanganan di luar kewenangan guru bimbingan karir atau bimbingan konseling maka siswa direferensikan ke psikolog.

Berikut contoh panduan wawancara psikolog kepada guru untuk memantau perkembangan anak didik di sekolah.

$\begin{array}{lc}\text { Pedoman Wawancara Kepada Guru } \\ \text { Nama Lengkap Anak } & : \\ \text { Jenis Kelamin } & : \\ \text { Tempat / tanggal lahir } & : \\ \text { Pendidikan Anak } & : \\ \text { Alamat Anak } & : \\ \text { Nama Guru } & : \\ \text { Pendidikan Guru } & : \\ \text { Alamat } & :\end{array}$

1. Apakah saudara mendapat kesan, bahwa di sekolah anak tersebut merasa dirinya seperti di rumahnya?

2. Apakah anak tersebut dapat menyesuaikan diri dengan baik, bila ia menerima tugas yang baru?

3. Apakah dengan tanpa ditanya anak tersebut berbicara mengenai ibunya?

4. Apakah anak tersebut pemalu?

5. Apakah anak tersebut menarik diri dari kesibukan kelompok? 
6. Apakah anak tersebut mencari bantuan dan pertolongan dari gurunya?

7. Apakah anak tersebut ikut serta dalam Permainan kelompok?

8. Apakah anak tersebut suka berjalan - jalan di kelas selama berlangsungnya pelajaran?

9. Apakah anak tersebut dengan cara yang khusus berusaha menarik perhatian anak lain?

10. Apakah anak tersebut ada kontak dengan anak - anak lain?

11. Apakah pada umumnya anak tersebut mempunyai minat terhadap tugasnya?

12. Apakah anak tersebut tidak dapat berdiri sendiri dan meminta pertolongan gurunya?

13. Apakah anak dapat menyesuaikan diri dengan kelompok kelasnya?

14. Apakah anak tersebut dapat memusatkan perhatiannya pada waktu mengerjakan tugasnya dan di dalam bermain?

15. Apakah anak dengan cara khusus berusaha menarik perhatian guru?

16. Apakah anak tersebut dapat mengikuti ketentuan - ketentuan sesuatu kelompok bermain?

17. Apakah anak tersebut berusaha untuk mendengarkan dengan penuh perhatian dan memberikan prestasi yang baik?

18. Apakah anak tersebut memperlihatkan kebutuhan untuk berlindung kepada guru?

19. Apakah anak tersebut memperlihatkan arah di dalam melaksanakan prestasinya? (Inginkah menyelesaikan suatu tugas yang telah dimulai)

20. Apakah anak tersebut mengikuti ajakan gurunya dan apakah hal itu berlangsung dengan tidak menentang?

21. Hal - hal menyolok:
a. Kidal
b. Menggigit - gigit kuku
c. Berkaca mata
d. Perengek
e. Tidak patuh
f. Masih senang bermain - main
g. Pelamun
h. Pemalas
i. Tampak seperti kanak - kanak
j. Berbadan tegap
k. Pendegarannya kurang baik
1. Mengisap jempol
m. Penglihatan kurang baik
n. Sangat banyak bergerak
o. Sangat lamban
p. Penakut
q. Cepat lelah
r. Lalai
s. Sangat pemalas
t. Gangguan bicara

22. Apakah saudara berpendapat anak tersebut sudah mampu untuk bersekolah?

\section{c. Instrumen}

1. Alat tulis

2. Alat perekam

3. Ruangan

4. Meja dan Kursi 


\section{d. Metode :}

Metode praktikum yang digunakan adalah dengan melakukan wawancara ke sekolah, menentukan satu siswa SD/SMP/SMA.

\section{e. Prosedur :}

1. Mahasiswa menentukan tema tertentu untuk melakukan wawancara

2. Mahasiswa diminta membuat pedoman wawancara pendidikan

3. Mahasiswa menentukan itee di sekolah sesuai tema masing - masing

4. Mahasiswa diminta mencatat semua data yang diperolehnya

5. Membuat laporan wawancara pendidikan sesuai permasalahan yang ditemukan

\section{Tugas dan Lembar Kerja}

1. Kapan psikolog pendidikan atau psikolog sekolah dibutuhkan?

2. Apakah hal-hal menyolok yang menjadi perhatian guru terhadap siswa?

Lembar Kerja: dikerjakan berdasarkan prosedur praktikum 


\section{FORMAT LAPORAN PRAKTIKUM WAWANCARA \\ WAWANCARA PENDIDIKAN}

I. Cover

II. Tujuan Wawancara

III. Pedoman Wawancara

IV. Riyawat Hidup

V. Permasalahan siswa

VI. Hasil Wawancara

\begin{tabular}{|l|l|l|l|l|}
\hline Verbatim & Probing & Opening & Closing & Permasalahan \\
\hline & & & & \\
\hline & & & & \\
\hline & & & & \\
\hline & & & & \\
\hline & & & & \\
\hline & & & & \\
\hline & & & & \\
\hline & & & & \\
\hline & & & & \\
\hline & & & & \\
\hline
\end{tabular}

VII. Kesimpulan

Sidoarjo, 2016

Tanda tangan

Nama Lengkap

$\mathrm{Nim}$

\section{Kunci}

Lihat halaman $38-41$

\section{Referensi}

1. Ormrod, J.E. 2008. Psikologi Pendidikan Membantu Siswa Tumbuh dan Berkembang. Jakarta: Erlangga.

2. Balgies, S. 2011. Wawancara Teori dan Aplikasi dalam Psikodiagnostik. Surabaya: IAIN Sunan Ampel Press. 


\section{G. MODUL 7: KETERAMPILAN WAWANCARA UNTUK KONSELING/ KLINIS}

\section{Pendahuluan}

Wawancara konseling merupakan wawancara yang paling sensitif dari seluruh bentuk wawancara. Wawancara konseling tidak akan terjadi kecuali bila ada seseorang yang merasa tidak mampu menangani sendiri problemnya dan memerlukan bantuan orang lain atau konselor yang menentukan sesi-sesi konseling yang dibutuhkan. Masalah yang dihadapi mungkin saja bersifat sangat pribadi misalnya persoalan-persoalan keuangan, stabilitas emosional, kesehatan fisik, pernikahan, moral, hubungan tidak harmonis antara anak dan orang tua, atau duka cita atas kematian teman dan anggota keluarga. Konseling merupakan proses membantu seseorang untuk memperoleh pemahaman tentang masalahnya serta menemukan jalan untuk menanggulanginya.

\section{Penyajian (Tutorial)}

\section{a. Tujuan}

Tujuan praktikum ini adalah mahasiswa memahami dan mampu mempraktekkan keterampilan dasar konseling, serta mampu menentukan area permasalahan dari proses konseling.

\section{b. Materi}

\section{Dua Pendekatan Dasar untuk Wawancara Konseling}

\section{Konseling Directive (Penyuluhan terarah)}

Karakteristiknya adalah iter menyerang langsung ke masalah, mengontrol struktur wawancara, memutuskan untuk menyelesaikan atau menghindari masalah subjek, dan menyusun langkah - langkah dalam wawancara. Iter mengumpulkan informasi, menganalisis masalah, memberikan pendapat, memberi solusi - solusi, memberi arahan yang spesifik kepada itee. Diasumsikan bahwa iter lebih mampu dibanding itee dalam memecahkan masalah.

\section{Keuntungan Konseling direcitive adalah :}

- Cukup mudah untuk memimpin dan mempelajarinya

- Tidak memerlukan waktu yang banyak

- Konselor fokus pada kepentingan masalah yang spesifik

- Membolehkan konselor untuk memberikan informasi dan pedoman penting

- Memperbolehkan konselor untuk melayani seperti penasehat ketika klien merasa segan dan tidak sanggup untuk menganalisis masalahnya atau untuk memperkirakan kemungkinan - kemungkinan solusinya.

\section{Konseling Non-directive}

Karakteristiknya adalah iter dipandang sebagai fasilitator / penolong pasif bukan sebagai ahli. Iter membantu klien memperoleh informasi, mendapat insight, menyelidiki masalah serta menganalisisnya, menemukan dan mengevaluasi solusinya, mendengarkan, mengobservasi, dan memberi harapan (mendorong) bukannya 
memaksakan ide dan solusi. Konseling berpusat pada klien, klien yang mengontrol struktur wawancara, menentukan topik apa yang akan didiskusikan, kapan mereka akan berdiskusi dan bagaimana mereka akan berdiskusi, menentukan langkah langkah dalam diskusi serta lamanya waktu diskusi. Diasumsikan bahwa (1) Setiap orang punya kemampuan untuk mencapai pemecahan terbaik yang ia miliki, (2) Hanya klien yang dapat memutuskan apa yang terbaik untuknya, (.) Hal terpenting dalam konseling adalah mendengar.

\section{Keuntungan konseling non-directive :}

- Membolehkan klien untuk mengungkapkan apa yang lebih penting untuk dirinya pada waktu yang diperlukan

- Membolehkan klien menyampaikan informasi dengan sukarela yang mungkin saja konselor tidak memikirkan hal itu

- Menyerahkan kepada klien untuk lebih mengontrol keputusan serta tindakannya

- Non-directive mungkin dapat mendorong klien untuk memberikan jawaban dan komentar secara mendalam

- Memberikan konselor kesempatan untuk mendengarkan dan mendorong klien

- Non-directive memungkinkan adanya komunikasi pada klien bahwa konselor sungguh tertarik padanya dan tidak terbaru - buru untuk menerima klien lain ataupun mengerjakan tugas lainnya.

Konselor yang terdiri dari konselor akademik, konselor pada perlindungan sosial (Social Security), konselor pernikahan dan konselor kesehatan selalu menggunakan kombinasi yang tepat antara pendekatan directive dan non-directive. Contohnya, selama bagian pertama dari wawancara dengan keluarga, konselor pelayanan sosial mungkin menggunakan pendekatan directive untuk mendapatkan informasi tentang keluarga tersebut seperti usia, jenis kelamin, pendapatan, alamat, pekerjaan, masalah masalah kesehatan, dan lain - lain. Konselor mungkin pindah ke pendekatan nondirective ketika mencoba untuk menemukan masalah keluarga lalu menghadapi masalah tersebut, bagaimana anggota keluarga tersebut merasakan masalahnya, dan apakah mereka mengharapkan pelayanan sosial. Tugas yang sulit dari konselor adalah menentukan pendekatan khusus yang tepat dan merubah dari satu pendekatan ke pendekatan yang lain selama wawancara konseling.

\section{Tujuan Wawancara konseling adalah :}

- Membantu klien menemukan insight atau pemahaman akan masalahnya atau situasinya dengan mengeksplorasi perasaan, pikiran dan sudut pandangnya.

- Fakta terkait masalah dilihat secara jelas dan realistis.

- Menolong klien untuk dapat melihat alternatif jalan menyelesaikan masalahnya.

\section{c. Instrumen}
1. Alat perekam
2. Alat tulis
3. Ruangan
4. Meja dan Kursi

\section{d. Metode}

Metode praktikum yang digunakan adalah dengan mencari klien untuk diwawancarai 


\section{e. Prosedur:}

1. Mahasiswa diberikan instruksi untuk praktikum wawancara konseling

2. Mahasiswa diminta mencari klien untuk diwawancarai

3. Mahasiswa diminta mencatat semua data yang diperolehnya

4. Mahasiswa diminta mencatat kekurangan dan kelebihannya selama melakukan wawancara konseling

5. Membuat laporan wawancara untuk konseling

\section{Tugas dan Lembar Kerja}

1. Apakah tujuan wawancara konseling?

2. Apa keuntungan wawancara konseling directive?

3. Apa peran iter dalam wawancara konseling non-directive?

Lembar Kerja: dikerjakan berdasarkan prosedur praktikum 
FORMAT LAPORAN PRAKTIKUM WAWANCARA

WAWANCARA KONSELING/KLINIS

I. Identitas Itee

II. Pendekatan konseptual yang digunakan

III. Hasil observasi awal

IV. Verbatim

V. Analisis hasil wawancara (Pertanyaan, Respon, Tema)

\begin{tabular}{|l|l|l|l|}
\hline \multirow{2}{*}{ Verbatim } & \multicolumn{3}{|c|}{ Analisis Hasil Wawancara } \\
\cline { 2 - 4 } & Pertanyaan & Respon & Tema \\
\hline & & & \\
\hline & & & \\
\hline & & & \\
\hline & & & \\
\hline
\end{tabular}

VI. Kesimpulan Wawancara

Sidoarjo, 2016

Tanda tangan

Nama Lengkap

Nim

\section{Kunci Tugas}

Lihat halaman $38-41$

\section{Referensi}

1. Atamimi, N. 2002. Hand-Out Asesmen \& Intervensi. Konseling. Yogyakarta: Program Profesi Fakultas Psikologi Universitas Gadjah Mada.

2. Andayani, B. 2002. Hand-Out Asesmen \& Intervensi. Wawancara. Yogyakarta: Program Profesi Fakultas Psikologi Universitas Gadjah Mada. 


\section{H. MODUL 8: DISKUSI KELOMPOK TERARAH (DKT)}

\section{Pendahuluan}

Wawancara kelompok disebut juga diskusi kelompok terarah atau focus group discussion (FGD). Mulanya metode ini dikembangkan oleh kelompok dari bidang pemasaran industri. Metode ini dapat digunakan untuk mengungkapkan motivasi yang mendasari perilaku pembeli. Di bidang pemasaran DKT digunakan untuk mengumpulkan pendapat tentang suatu produk.

DKT, seperti juga terapi kelompk telah dimodifikasi sesuai dengan kebutuhan. Pada awalnya moderator dalam teknik ini sering terdiri atas para klinisi sehingga fokus sering pada psikodinamika pembeli. Dalam DKT digunakan kelompok terarah. Dalam Balgies (2011) kelompok terarah adalah suatu tipe kelompok tertentu dalam arti tujuan, besarnya, komposisinya, dan prosedurnya. Tujuan kelompok ini adalah mengumpulkan pendapat suatu kelompok mengenai suatu hal.

Contoh dalam bidang pemasaran tentu yang akan dikumpulkan adalah pendapat konsumen tentang suatu produk. Motivasi-motivasi konsumen untuk membeli suatu produk dapat pula diketahui. Kelompok terarah biasanya terdiri atas tujuh sampai sepuluh orang. Biasanya mereka tidak mengenal satu sama lain. Mereka diseleksi karena mempunyai karakteristik yang sama sehubungan dengan topik yang dibicarakan dalam kelompok.

\section{Penyajian (Tutorial)}

\section{a. Tujuan}

Tujuan praktikum ini adalah mahasiswa memahami teknik DKT dan dapat memerankan sebagai pemandu dalam proses DKT, serta mampu menentukan area permasalahan sebagai bahan diskusi.

\section{b. Materi}

DKT juga disebut wawancara kelompok oleh Morgan dalam Perwitasari (2002). Yang sering digunakan adalah kelompok terarah. Menurut Krueger dalam Perwitasari (2002) bahwa anggota kelompok biasanya tidak mengenal satu sama lain. Yang penting, sebetulnya dalam kelompok terartah adalah homogenitas anggota. Dalam terapi kelompok anggota yang homogen memudahkan kepemimpinan terapis, terutama terapis baru. Homogen disini berarti bahwa kelompok terdiri atas sekelompok orang yang mempunyai kareakteristik tertentu. Misalnya remaja, dewasa, laki-laki, sama minatnya, setara sosial ekonominya, dapat merupakan karakteristik yang merupakan kriteria homogenitas dalam kelompok terarah.

Steward dan shamdasani dalam Prawitasari (2011) menyebutkan adanya keterbatasan kelompok terarah. Kedua ahli ini mengingatkan bahwa kelompok terarah bukan merupakan obat mujarab bagi setiap kebutuhan penelitian. Keterbatasan tersebut yakni dibutuhkannya pemandu yang mempunyai keterampilan dalam interaksi sosial.

Ia perlu mempunyai karakteristik tertentu seperti syarat pemimpin yang baik dalam terapi kelompok (Prawitasari, 1991). Syarat tersebut antara lain adalah penerimaan tanpa penilaian, empati, kepekaan, terhadap komunikasi non-verbal, tegas tetapi halus dalam memotong anggota yang sangat dominan, mendorong anggota yang pasif untuk memberikan pendapatnya, mengarahkan diskusi pada topik yang telah ditentukan 
sebelumnya. Syarat pemandu yang baik ini perlu dipenuhi untuk memperoleh data yang optimal. Kriteria pemandu:

- Mengetahui tujuan diskusi

- Mememberikan stimulasi antar partisipan

- Mampu memiliki keterampilan komunikasi

- Mendorong orang untuk partisipasi

- Mampu menyikapi perbedaan dan membuatknya harmonis

- Membimbing kelompok dari satu topik ke topik lain

- Tidak boleh memaksakan kehendak

- Mengendalikan diskusi

KETERAMPILAN PEMANDU

Keterampilan Substantif:

(1) Klarifikasi;

(2)Refleksi;

(3) Memotivasi\&Probing

(4) Mengembangkan sensitivitas

Keterampilan Proses:

(1) Memulai diskusi;

(2) Blocking\&distribusi;

(3) Refokus;

(4) Melerai perdebatan:

(5) Reframing;

(6) Menegosiasi waktu;

(7) Memberi toleransi jeda;

(8) Merangkum dan menutup diskusi

PEMBENTUKAN TIM

- 1 moderator = bertugas sebagai fasilitator diskusi

- 1 pencatat proses= mengamati proses DKT, membantu moderator

- 1 penghubung peserta= mengenal dan mau menghubungi dan memastikan partisipasi peserta

- 1 bloker = mencegah adanya gangguan dari pihak luar selama DKT

- 1-2 orang logistik = membantu transport, kebutuhan rehat dll

Merekrut anggota/peserta:

- Peserta harus tahu/bahkan mengalami materi diskusi

- Pengalaman dalam hal materi diskusi hendaknya heterogen

- Sementara faktor lain dapat homogen, mis: jenis kelamin, usia, pendidikan, pekerjaan, status sosial ekonomi.

- Kalau terlalu heterogen susah karena variasi terlalu besar

Contoh topik:

- Masalah remaja: free sex, narkoba, penilaian tentang UN...

- Masalah politik: sikap terhadap pemerintah, korupsi, pemilu...

- Masalah industri: minat konsumen, respon terhadap produk, kepemimpinan, kepuasan

- Masalah kesehatan: pelayanan Puskesmas, mencegah penyakit menular

- Kasus sosial: gelandangan, bencana, anak jalanan... 


\section{PROSEDUR DKT:}

- Pemandu membuat pedoman DKT

- Pedoman DKT berisi prosedur DKT yang harus ditaati pemandu, kasus/kejadian yg akan didiskusikan serta pertanyaan terkait kasus/kejadian tersebut

- Pemandu memberikan pengantar (paling lama 15 menit) yaitu memotivasi peserta untuk terlibat, berani mengemukakan pendapat, dan bekerjasama dengan baik, menyampaikan tujuan dan perkenalan pemandu dengan anggota

- Permintaan ijin untuk melakukan perekaman dan jika ada hal-hal yang rahasia harus jadi rahasia kelompok tidak boleh sampai keluar

- Diskusi berlangsung $1-2$ jam

- Pemandu merangkum hasil DKT dan pemberian kesempatan pada peserta untuk memberikan informasi tambahan 10 menit

- Pemandu menutup diskusi dengan ucapan terima kasih atas partisipasi dan pentingnya informasi yang diberikan

\section{c. Instrumen}
1. Ruangan
2. Kursi
3. Alat tulis

\section{d. Metode}

Metode yang digunakan dalam praktikum ini adalah diskusi tentang suatu tema yang ditentukan kelompok.

\section{e. Prosedur}

1. Mahasiswa diberikan instruksi untuk praktikum DKT

2. Mahasiswa diminta membentuk kelompok DKT

3. Mahasiswa diminta menentukan pemandu DKT

4. Mahasiswa diminta mencatat kekurangan dan kelebihan pemandu selama melakukan DKT

5. Membuat laporan hasil DKT

\section{Tugas dan Lembar Kerja}

1. Apa kriteria pemandu dalam DKT?

2. Bagaimana prosedur DKT?

3. Apa maksud reframing dalam keterampilan proses pada pemandu?

4. Topik apa saja yang bisa digunakan sebagai DKT?

Lembar Kerja: dikerjakan berdasarkan prosedur praktikum 


\section{FORMAT LAPORAN PRAKTIKUM DKT}

I. Identitas Pemandu

II. Topik Diskusi

III. Hasil observasi awal

IV. Verbatim

V. Analisis hasil DKT

\begin{tabular}{|l|l|l|l|}
\hline \multirow{2}{*}{ Verbatim } & \multicolumn{3}{|c|}{ Analisis Hasil DKT } \\
\hline & Pemandu & Anggota & Tema \\
\hline & & & \\
\hline & & & \\
\hline & & & \\
\hline & & & \\
\hline & & & \\
\hline & & & \\
\hline & & & \\
\hline
\end{tabular}

VI. Kesimpulan

Sidoarjo, 2016

Tanda tangan

Nama Lengkap

NIM

\section{Kunci}

Lihat halaman $38-41$

\section{Referensi}

1. Prawitasari, J.E. 2002. Hand-Out Asesment \& Intervensi. Diskusi Kelompok Terarah. Yogyakarta: Program Profesi Fakultas Psikologi Universitas Gadjah Mada.

2. Balgies, S. 2011. Wawancara Teori \& Aplikasi dalam Psikodiagnostik. Surabaya: IAIN Sunan Ampel Press.

3. Jacobs, Ed E.; Masson, R.L.; Harvill,R.L. 2009. Group Counseling Strategies and Skills. USA: Thompson Brooks. 


\section{KUNCI TUGAS MODUL 1 - 8}

\section{Kunci Tugas Modul 1}

1. a. Apakah Anda menikmati acara itu?

b. Dimana Anda saat kejadian itu?

c. Kapan Anda mulai merasakan ada keganjilan itu?

d. Siapa yang memelopori kegiatan itu?

e. Mengapa Anda melakukan itu?

f. Bagaimana Anda menyampaikan kabar itu padanya?

2. a. Tata bahasa, yaitu menggunakan bahasa Indonesia yang baku, memperhatikan cara pandang itee, dan membuat pertanyaan sejelas mungkin bagi itee.

b. Kesinambungan, yaitu adanya keterkaitan antara satu pertanyaan dengan pertanyaan berikutnya, memberikan penjelasan jika pertanyaan kurang relevan, dan menyampaian pertanyaan di waktu yang tepat.

c. Tingkat pengetahuan, yaitu iter hendaknya memberikan pertanyaan disesuaikan dengan tingkat pengetahuan itee, agar komunikasi tetap terjalin dua arah, dan itee tidak segan dalam menyampaikan permasalahannya.

3. Nudging probes, yaitu memberikan respon dengan kata atau frase

Misal: Lalu?

Jadi?

Teruskan, apa yg terjadi kemudian?

Bagaimana respon anda?

Mengapa?

4. Pertanyaan terbuka, yaitu pertanyaan yang bersifat luas, tidak terbatas lingkup dan arah, sehingga informasi yang diperoleh lebih banyak. Cara menyampaikan pertanyaan terbuka yaitu dengan:

1) Menciptakan rapport, percakapan yang berkesinambungan

2) Diawali dengan 5W (lima kata tanya: what, where, why, who, when dan ceritakan tentang....

3) Gambarkan .... dengan cara apa ....

4) Menggabungkan opini, sudut pandang, pikiran dan perasaan

5. a. Pertanyaan Primer, ialah pertanyaan dasar yang diberikan untuk mengawali suatu topik pembicaraan dengan itee.

b. Pertanyaan Sekunder, ialah pertanyaan lanjutan yang mengikuti pertanyaan primer dalam upaya untuk mendapatkan informasi lebih lanjut dari itee.

6. Pertanyaan yang bersifat terbatas, jawaban atas pertanyaan sangat sempit dan mengarah namun tidak selalu dangkal.

\section{Kunci Tugas Modul 2}

1. Menunjukkan sikap penuh perhatian dan memberikan umpan balik yang sesuai, serta menunjukkan ketertarikan, siap dengan pesan verbal dan non-verbal. 
2. Iter dapat memberikan ekspresi yang meyakinkan bahwa ia dapat merasakan hal yang dirasakan itee, sehingga dapat memberikan respon dengan tepat, penuh pengertian, penuh keyakinan dan dapat memberikan kenyamanan dan kehangatan kepada itee.

3. Perilaku motorik (gaya, tingkat koordinasi, tingkat aktivitas: hiper/hipoaktivitas, tremor, kecerobohan, senyum, gerak bergoyang, gerak stereotip); Postur dan perubahannya (santai, kaku, tegang,membungkuk,tegak,lemas); Ekspresi wajah dan kesesuaian dengan isi wawancara (waspada, kosong, tumpul, tersenyum, cemberut, tertegun, cemas, marah, sedih, kacau); Kontak mata (terus menerus atau tidak sama sekali).

4. Iter memberikan respon untuk menggali lebih mendalam tentang hal yang disampaikan itee dengan kata-kata: "maksudmu...."; "kamu tampak seperti...."

\section{Kunci tugas modul 3}

1. Langkah pertama yaitu membangun rapport, perkenalan, mengucap salam, aktivitas non verbal, percakapan topik umum dan ringan, dan personal inquiry

2. Highly scheduled interview yaitu Memuat seluruh pertanyaan dan penggunaan bahasa/pilihan kata dan kalimat

3. Sebagai pesan mengakhiri wawancara tetapi tidak mengakhiri hubungan, wawancara diakhiri dengan baik, menyimpulkan materi wawancara

4. Bersandar ke depan, bergerak menjauhi itee, berdiri, melepas silangan tangan, menaruh tangan di atas paha, mengajak berjabat tangan, melirik jam

\section{Kunci tugas modul 4}

1. Wawancara survei adalah wawancara yang dilakukan untuk mendapatkan informasi tentang obyek tertentu kepada itee

2. Langkah-langkah wawancara survei yaitu: Menetapkan tujuan, mencari topik penelitian, menyusun wawancara, mengembangkan pertanyaan, memilih itee, melakukan penelitian, analisis hasil wawancara

3. Iter hendaknya menjalin hubungan baik dengan itee, melibatkan empati sehingga itee tidak merasa kaku dalam proses wawancara agar informasi yang dibutuhkan bisa diperoleh

\section{Kunci tugas modul 5}

1. Diberikan pertanyaan:

Mengapa Anda tertarik pekerjaan ini?;

Apakah hal yang menyenangkan dari pekerjaan ini?;

Seandainya jaminan tidak memuaskan apakah Anda masih menyukai pekerjaan ini? 
2. Diberikan pertanyaan:

Apa yang Anda lakukan jika dalam waktu luang?;

Apakah suka nonton atau memancing? Atau aktivitas lain? Bisa diceritakan?

3. Memberikan pertanyaan:

Apakah saudara merasa masih perlu belajar banyak pada bidang yang akan saudara tekuni?;

Dapatkah saudara bekerja dengan baik jika ada orang lain yang memperhatikan kerja saudara?;

Dalam mengerjakan sesuatu perintah, saudara lebih senang berpegang pada peraturan yang sudah ditentukan (SOP) ataukah mencoba mengerjakan dengan cara saudara sendiri?;

Dapatkah saudara bekerja lama tanpa bersitirahat?

Saudara lebih senang beberapa kali beristirahat sebentar, ataukah sesudah bekerja lama lalu beristirahat?

\section{Kunci Tugas Modul 6}

1. Psikolog berperan ketika guru bimbingan karir atau bimbingan konseling tidak mampu menangani siswa yang bermasalah hingga membutuhkan konseling lanjut atau terapi.

2. Hal-hal menyolok yang perlu menjadi perhatian guru pada siswa,

Misalnya:

Penakut, pemalas/motivasi rendah, pemurung, lalai, cepat lelah, sangat lamban, suka melamun, tidak patuh.

\section{Kunci Tugas Modul 7}

1. Tujuan wawancara konseling adalah membantu klien insight atau memahami masalahnya atau situasinya dengan mengeksplorasi perasaan, pikiran dan sudut pandangnya; melihat permasalahan yang sebenarnya secara jelas dan realistis; dan membantu klien menemukan solusi alternatif.

2. Keuntungan wawancara konseling directive adalah:

- Cukup mudah untuk memimpin dan mempelajarinya

- Tidak memerlukan waktu yang banyak

- Konselor fokus pada kepentingan masalah yang spesifik

- Membolehkan konselor untuk memberikan informasi dan pedoman penting

- Memperbolehkan konselor untuk melayani seperti penasehat ketika klien merasa segan dan tidak sanggup untuk menganalisis masalahnya atau untuk memperkirakan kemungkinan - kemungkinan solusinya.

3. Iter berperan sebagai fasilitator pasif bukan sebagai ahli. Iter membantu klien memperoleh informasi, mendapat insight, menyelidiki masalah serta menganalisisnya, menemukan dan mengevaluasi solusinya, mendengarkan, mengobservasi, dan memberi harapan /motivasi untuk mencapai solusi. 


\section{Kunci Tugas Modul 8:}

1. Kriteria pemandu dalam DKT adalah mengetahui tujuan diskusi, memberikan stimulasi antar partisipan, mampu memiliki keterampilan komunikasi, mampu memotivasi anggota untuk partisipasi, mampu menyikapi perbedaan dan membuatnya harmonis, mampu membimbing kelompok dari satu topik ke topik lain, tidak boleh memaksakan kehendak, mampu mengendalikan diskusi.

2. Prosedur DKT yaitu

a. Pemandu membuat pedoman DKT

b. Pedoman DKT berisi prosedur DKT yang harus ditaati pemandu, kasus/kejadian yg akan didiskusikan serta pertanyaan terkait kasus/kejadian tersebut

c. Pemandu memberikan pengantar (paling lama 15 menit) yaitu memotivasi peserta untuk terlibat, berani mengemukakan pendapat, dan bekerjasama dengan baik, menyampaikan tujuan dan perkenalan pemandu dengan anggota

d. Permintaan ijin untuk melakukan perekaman dan jika ada hal-hal yang rahasia harus jadi rahasia kelompok tidak boleh sampai keluar

e. Diskusi berlangsung $1-2$ jam

f. Pemandu merangkum hasil DKT dan pemberian kesempatan pada peserta untuk memberikan informasi tambahan 10 menit

g. Pemandu menutup diskusi dengan ucapan terima kasih atas partisipasi dan pentingnya informasi yang diberikan

3. Reframing adalah membuka pandangan baru bagi anggota terkait topik diskusi sehingga suasana diskusi tetap hangat.

4. Contoh topik:

a. Masalah remaja: free sex, narkoba, penilaian tentang UN...

b. Masalah politik: sikap terhadap pemerintah, korupsi, pemilu...

c. Masalah industri: minat konsumen, respon terhadap produk, kepemimpinan, kepuasan

d. Masalah kesehatan: pelayanan Puskesmas, mencegah penyakit menular

e. Kasus sosial: gelandangan, bencana, anak jalanan... 


\section{Lampiran}

\section{Riwayat Hidup Penulis 1}

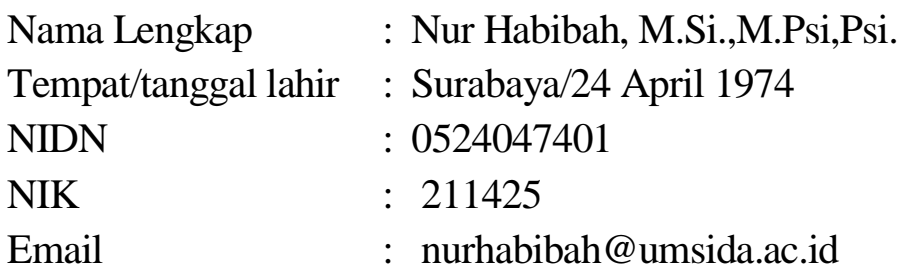

Penulis merupakan dosen tetap di Fakultas Psikologi Universitas Muhammadiyah Sidoarjo sejak tahun 2011. Sebelumnya penulis mengawali karir sebagai tim Psikologi di jurusan Akuntansi Fakultas Ekonomi Universitas Islam Indonesia (UII) Yogyakarta. Penulis mengenyam pendidikan S1 di Fakultas Psikologi Universitas Darul 'Ulum Jombang pada 1993-1998, kemudian tahun 2003 lulus dari pendidikan S2 Program Pascasarjana Universitas Gadjah Mada Program Studi Psikologi dan pada 2010 lulus dari Magister Profesi Psikologi Universitas Islam Indonesia. Saat ini penulis mendapat amanah sebagai Kasie Layanan Psikologi Universitas Muhammadiyah Sidoarjo.

\section{Riwayat Hidup Penulis 2}

\begin{tabular}{|c|c|}
\hline $\mathrm{Nam} \mathrm{a}$ & : Dra. Dwi Nastiti, MSi. \\
\hline Tempat/tgl lahir & : Mojokerto, 19 Oktober 1963 \\
\hline Alamat & : Kompleks Ratatex no. 56, Balongbendo,Sidoarjo. \\
\hline Pendidikan & $\begin{array}{l}\text { : a. Dalam Negeri : } \begin{array}{l}\text { 1. S1 Fakultas Psikologi Ubaya Surabaya } \\
\text { (Psikologi) } \\
\text { 2. S2 Fakultas Psikologi Untag Surabaya } \\
\text { (Psikologi Pendidikan) }\end{array}\end{array}$ \\
\hline & b. Luar Negeri \\
\hline Pekerjaan & $\begin{array}{l}: \text { Dosen Tetap UMSIDA } \\
\text { SK. No. : E.6/103/BPH-UMSIDA/VII/2011 }\end{array}$ \\
\hline Pangkat/Golongan & : Pembina / IV-A \\
\hline Jabatan & : Lektor Kepala \\
\hline Inpassing & : dlm pangkat Pembina, gol. IV/a (31-12-2010) \\
\hline NIDN & : 0718106303 \\
\hline NIK & : 210372 \\
\hline Email & nastitidwi19@yahoo.co.id \\
\hline No. sertifikasi & 11107106002925 \\
\hline
\end{tabular}




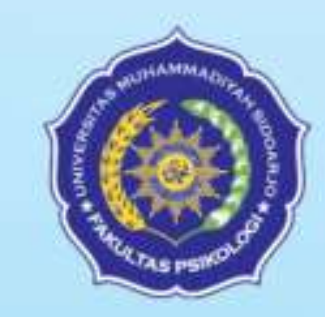

FAKULTAS PSIKOLOGI

\section{UNIVERSITAS MUHAMMADIYAH SIDOARJO}

